\title{
THE ORIGIN AND DEVELOPMENT OF THE SOUTH AFRICAN ARMY
}

\author{
Sgt Ashley C. Lillie*
}

\section{Origin}

\section{The early years (1910-1912)}

The establishment of the Union of South Africa on 31 May 1910 saw the appointment of General J.C. Smuts as Minister of the Interior, Mines and Defence. Responsibilities of the Department of Defence were given as 'all matters in relation to defence, including local defence and Volunteer Forces, Militia, Cadet Corps, Rifle Associations and Clubs'. ${ }^{1}$ Before 1 July 1912, matters pertaining to defence were dealt with by a small section of the Department of the Interior. ${ }^{2}$ On 9 June 1910, Mr H.R.M. Bourne (later Sir Roland) was appointed Acting Under Secretary for the Interior responsible for defence matters.

No framework within which legal matters relating to defence could be dealt with had been created after Union, and they were therefore disposed of in terms of pre-existing colonial legislation. This situation was obviously unacceptable and a start was accordingly made in the creation of a Defence Act. As a result, a concerted effort by the Minister and a number of co-workers produced the 'Bill to Provide for the Defence of the Union and for matters incidental thereto' which appeared in the Union Gazette Extraordinary of 30 November 1911.

\section{Defence Act}

The Defence Act (Act 13 of 1912) was regarded as the most important piece of legislation passed that year. It attracted nationwide interest and comment as the result of the populace's intimate interest in defence affairs gained from their turbulent past. General Smuts had, in the Act, succeeded both in encompassing the military traditions of the past and in establishing an efficient defence system and it was readily accepted for this reason. The Act was assented to by the Governor-General on 13 June 1912 and promulgated on 14 June. After two years the fledgling Union now had its own Defence Force.

Before discussing the Act, it should be noted that the main principle of the measure was the liability of every citizen of European descent between the ages of 17 and 60 , to render, in times of war, personal service in defence of the Union in any part of South Africa whether in or outside the Union.

Over and above the obligations of citizens in time of war, every citizen was also liable to undergo a prescribed course of peace training for military service in the Union Defence Force. This service extended over a period of four years. Provision was however made for only fifty per cent of the citizens liable for training to undergo such. Those who were liable for training but not entered for service had to serve as members of Rifle Associations for four years. All others who were liable for service in time of war could also serve as members of Rifle Associations.

Persons not of European descent were not in any way liable to render either personal service in a combatant capacity in time of war or any other form of service. Nothing however prevented these groups from voluntary engagement in the Defence Forces.

\section{Establishment of the UDF}

\section{Early appointments}

On 1 July 1912 the posts of Commandant-General of the Cape Colonial Forces (Col H.T. Lukin), Commandant of Militia (Natal) (Sir Duncan McKenzie) and Inspector of Transvaal Volunteers (Col P.S. Beeves) were abolished. ${ }^{3}$ On the same date appointments to the HeadquarterStaff of the Defence Forces were made. Brigadier General Christian Frederick Beyers was appointed Commandant-General of the Citizen Force; Brigadier General Henry Timson Lukin, C.M.G., D.S.O. became Inspector-General of the Permanent Force, while Colonel Percival Scott Beves assumed the post of Commandant of Cadets. ${ }^{4}$ These three seperate and independent military executive commanders were controlled by the Minister who was in turn advised by the Council of Defence. This Council consisted of 


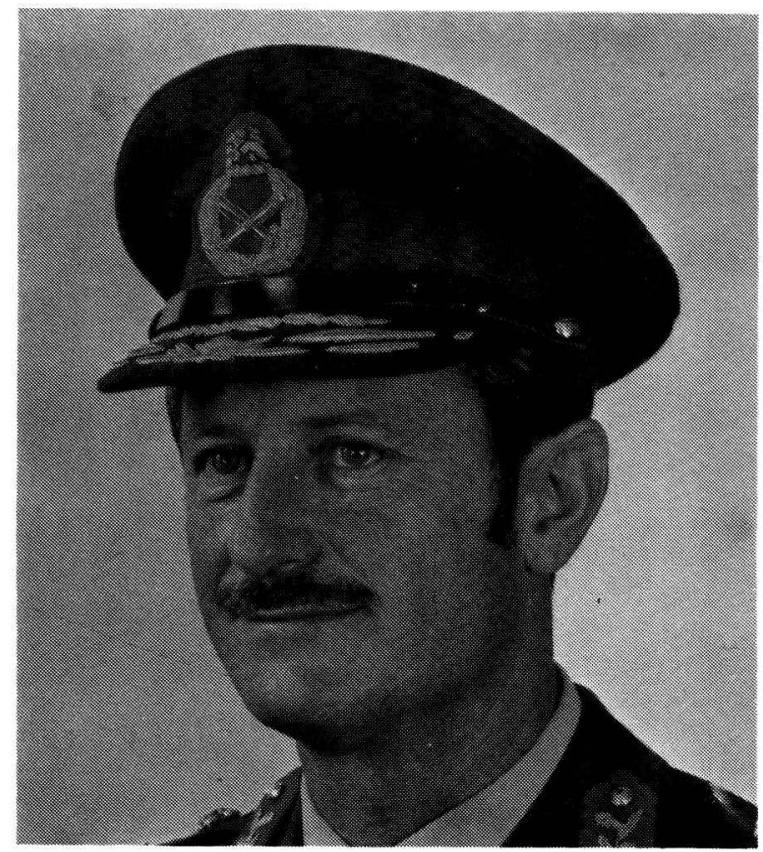

Lt-genI J.J. Geldenhuys, SSAS, SD, SM Chief of the Army since 7 October 1980, photographed when still Majorgenl

four experienced ex-soldiers, ${ }^{5}$ namely General S.W. Burger; Colonel the Hon. C.P. Crewe, C.B.; General the Hon. C.R. de Wet and Colonel Sir Duncan McKenzie, K.C.M.G. ${ }^{6}$ The Minister of Defence was ex officio President and the Secretary for Defence or any other member of the Department of Defence nominated by the Minister, was Secretary of the Council.

As from 1 July 1912 the Department of Defence became a separate department. Defence Headquarters were established at Pretoria and divided into three sections:

(a) the Secretariate - a civilian branch, including finance, controlled by the Under Secretary;

(b) the General Staff section which dealt with military organisation, training, appointments in the Permanent Force, registration of citizens for the Coast Garrison and Citizen Forces and other military matters referred to the section by the Minister;

(c) the Administrative section which was concerned with supplies, accomodation, transport, veterinary services and other services pertaining to administration, which the Minister might delegate.

The establishment of a headquarters made the appointment of Staff Officers in each of the military sections and commands necessary. The appointment of these officers, namely Major J.J.
Collyer as Staff Officer of General Staff duties, Lt Col M.C. Rowland as Staff Officer of Administrative duties and Major N.H.M. Burne, Major C. Burgess and Captain E. Christian as Staff Officers of Permanent Force, Citizen Force and Cadets respectively took place on 1 July $1912{ }^{7}$

The Union was divided into fourteen military districts in early November $1912^{8}$ (in July 1914 the districts were reorganized into fifteen districts) and later in the same month the newly-qualified District Staff Officers were posted to their respective districts. ${ }^{9}$

These officers included professional soldiers from the British Army and the Cape Mounted Riflemen as well as ex-Boer officers. With the exception of Lt Col L.J. Shadwell, p.s.c., they had all attended a District Staff Officers course at the South African Military School which had been established on 1 July $1912 .^{10}$ The School was originally situated at the Presidency, Bloemfontein, but on 1 January 1914 it moved to Tempe. The District Staff Officers were assisted by a Staff Adjudant, NCO instructors and a small clerical and stores staff. ${ }^{11}$ This organisation related to the Citizen Force, Cadets and Coast Garrison Force as well as Rifle Associations and Reserves, in fact everything, except the Permanent Force.

In terms of the Act the Defence Forces were organised into the following forces:

(i) Permanent Force.

(ii) Coast Garrison Force.

(iii) Citizen Force.

(iv) Royal Naval Volunteer Reserve.

(v) Any Special Reserve established under the Act.

\section{Permanent Force}

A major advance in the organization of the Defence Force was made on 1 April 1913 with the establishment of the Permanent Force in terms of Proclomation 219 of 13 December 1912. The units of the Permanent Force, known as the South African Mounted Riflemen, constituted the nucleus of the growing defence organization.

The S.A.M.R. consisting of five regiments was in reality a military constabulary similar to the Cape Mounted Riflemen (C.M.R.). Each of the regiments was alloted a portion of the Union in which it was charged with the duty of maintaining order. ${ }^{12}$ The S.A.M.R. consisted of former members of the C.M.R., the Cape Mounted Police, 


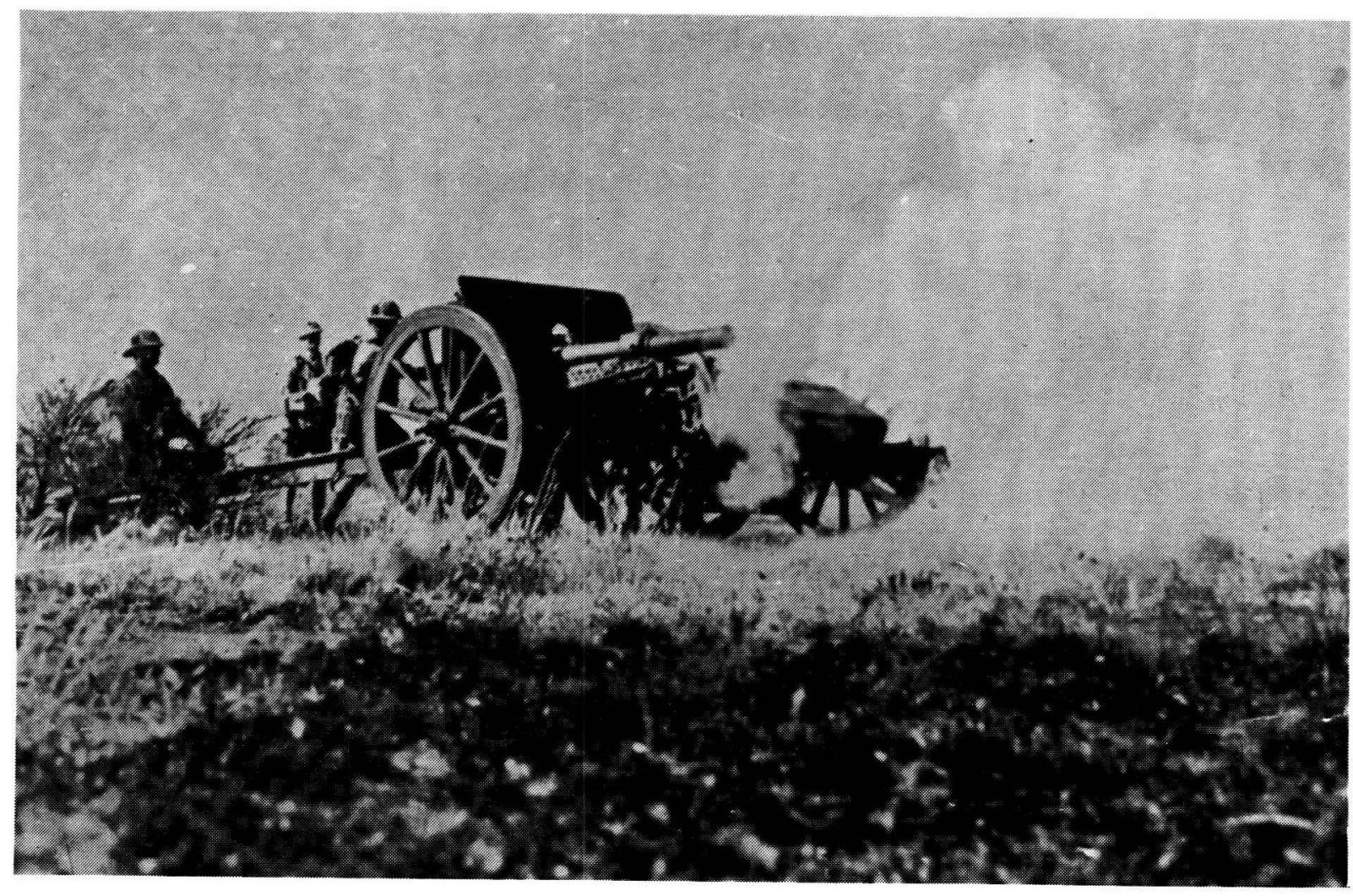

Artillery Training in South Africa

the District Mounted Police of the Cape Colony, the Natal Police, Transvaal Police and Orange River Colony Police. ${ }^{13}$

In terms of the Defence Act a permanent battery of artillery was to be a component of each regiment. As many members of the regiment as possible were to be trained in field artillery duties in addition to their duties as mounted riflemen. The location of headquarters of the five regiments were decided largely by existing accommodation. These were at King Williams Town, Pietermaritzburg, Dundee, Pretoria and Kimberley.

\section{Citizen Force}

On 30 June 1913 the Militia, Volunteer Corps and Cadet organizations of the Cape, Natal and Transvaal were disbanded. The following day saw the establishment of the Coast Garrison and Citizen Forces and the new Cadet organisation. ${ }^{14}$

The Corps of South African Garrison Artillery was established on 1 July 1913 with the 1st Division South African Garrison Artillery (Cape Garrison Artillery) being composed of the old Volunteer Corps of Cape Garrison Artillery. The nucleus of

the 2nd Division South African Garrison Artillery (Durban Garrison Artillery) consisted of "A" and "B" Batteries of Natal Field Artillery. ${ }^{15}$

On 1 July 1913, the date of their embodiment into the new active Citizen Force, the units incorporated underwent the following changes in designation: ${ }^{16}$

\section{Name prior to embodiment}

Cape Field Artillery

Cape Light Horse

Duke of Edinburgh's

Own Volunteer Rifles

Prince Alfred's Volunteer Guard

Queenstown Rifle Volunteers

First City Volunteers

\section{New name}

6th Citizen Battery (Prince Alfred's Own Cape Field Artillery).

5th Mounted Rifles (Cape Light Horse).

2nd Infantry (Duke of Edinburgh's Own Rifles).

3rd Infantry (Prince Alfred's Guard).

4th Infantry (1st Eastern Rifles (Queenstown)).

4th Infantry (1st Eastern Rifles (First City)). 
Kaffrarian Rifles

Kimberley Regiment

Duke of Connaught and Strathearn's Own Cape Town Highlanders

Uitenhage Volunteer Rifles

Prince of Wales' Own Regiment of Cape Peninsula Rifles

Cape Medical Corps (A Company)

Cape Medical Corps (B Company)

"C" Battery, Natal Field Artillery

Natal Carbineers

Natal Mounted Rifles

Umvoti Mounted Rifles

Border Mounted Rifles

Zululand Mounted Rifles

Durban Light Infantry Natal Medical Corps 5th Infantry (Kaffrarian Rifles).

7th Infantry (Kimberley Regiment).

6th Infantry (Duke of Connaught and Strathearn's Own Cape Town Highlanders)

3rd Infantry (Prince Alfred's Guard (Uitenhage)).

9th Infantry (Prince of Wales' Own Regiment of Cape Peninsula Rifles).

1st Mounted Brigade Field Ambulance (Cape), South African Medical Corps.

No 1 Company (Cape), South African Medical Corps.

7th Citizen Battery (Natal Field Artillery).

1st and 2nd Mounted Rifles (Natal Carbineers).

3rd Mounted Rifles (Natal Mounted Rifles).

3rd Mounted Rifles ("B" Squadron (Umvoti Mounted Rifles) of the Natal Mounted Rifles).

3rd Mounted Rifles ("C" Squadron (Border Mounted Rifles) of the Natal Mounted Rifles).

3rd Mounted Rifles ("D" Squadron (Zululand Mounted Rifles) of the Natal Mounted Rifles).

1st Infantry (Durban Light Infantry)

2nd Mounted Brigade Field Ambulance (Natal), South
African Medical Corps.

Transvaal Horse Artillery

Imperial Light Horse

8th Citizen Battery (Transvaal Horse Artillery).

4th Mounted Rifles (Imperial Light Horse)

Transvaal Scottish

8th Infantry (Transvaal Scottish).

Witwatersrand Rifles 10th Infantry (Witwatersrand Rifles).

Transvaal Cycle and Motor Corps

11th Infantry (Rand Light Infantry).

Transvaal Medical 1st Field Ambulance (Transvaal) South African Medical Corps.

The Natal Telegraph Corps and the Transvaal Signalling and Field Telegraph Coy were temporarily absorbed into the Active Citizen Force, but were disbanded on 1 November 1923.

At the time of their inception, the authorised establishment of the A.C.F. and C.G.F. was:

\section{Unit Strength}

2 Divisions S.A.G.A. 567

6 Batteries Field Artillery 504

16 Regiments of Mounted Rifles and 6 Independent Squadrons

12 Regiments of Dismounted Rifles and 6 Independent Squadrons

12 Infantry Battalions

6984

10 Brigade Trains, S.A.S.C.

6672

14 Subunits of the S.A.M.C. 358

1 Fortress Engineer Coy

The actual strength on 31 December 1913 was 23462 .

In terms of Government Notice No 1570 of 9 October 1913, the new Active Citizen Force units were spread throughout the military districts of the Union.

\section{Rifle Associations}

Rifle Associations existed in Natal and the Cape Colony prior to Union. Persons liable for service 
in the Rifle Associations had to serve for four consecutive years in terms of the Act. There were however considerable numbers of volunteers. Provision was made for the issue of a Government rifle and bandolier along with a free issue of ammunition to compulsory members of Rifle Associations. Provision was also made for boys between 13 and 17 to be Cadet members of Rifle Association in country districts. The Rifle Associations proved to be very popular and in the first year more than 42000 citizens joined. By 1919 the members numbered 99269

\section{Cadets}

The Cadet organizations were firmly established in the Cape, Natal and Transvaal, and when all pre-Union corps became embodied in the Union organization as from 1 July 1913, the strength was 11318.

\section{First Action and World War One}

The young army received its first call to arms with the Rand Strike of January 1914 when the Government mobilized ACF units and they together with the PF were able to overcome the grave cirsis which threatened the State.

Within a few days of the declaration of war in August 1914, the Imperial Government asked the Union Government to undertake the entire duty of protecting the borders and coast of the Union in order to release the Imperial Garrison. During the course of World War One, South Afri- can forces participated in campaigns in German South West Africa, German East Africa, Europe, Palestine and Egypt. The rebellion of 1914-15, for a time, also kept the Union forces occupied in campaigning.

\section{The inter-war period (1918-1938)}

\section{Rationalisation and economy}

A number of important administrative changes took place at DHQ during the War. The Commandant-General of the Citizen Force resigned his post in September 1914 and from that time the Minister of Defence exercised the powers attached to the post. On 1 July 1915 the designations of the officers in charge of the three military sections of Defence Headquarters were changed with Staff Officer for General Staff Duties being redesignated Chief Staff Officer, General Staff and Adjudant-General. ${ }^{17}$ The officer in charge of the Administrative Section became Quartermaster-General and the head of the Medical Services Section became Director of Medical Services. ${ }^{18}$ The name of the first of these posts was later changed again when on 4 June 1917 it became Chief of the General Staff and Adjudant-General. ${ }^{19}$

After the cessation of hostilities, a number of farreaching changes in the administration of the Defence Force took place. Purely military policy had formerly been directed by the Minister through the Secretary for Defence but in 1918 the responsibility for the co-ordination of all mili-

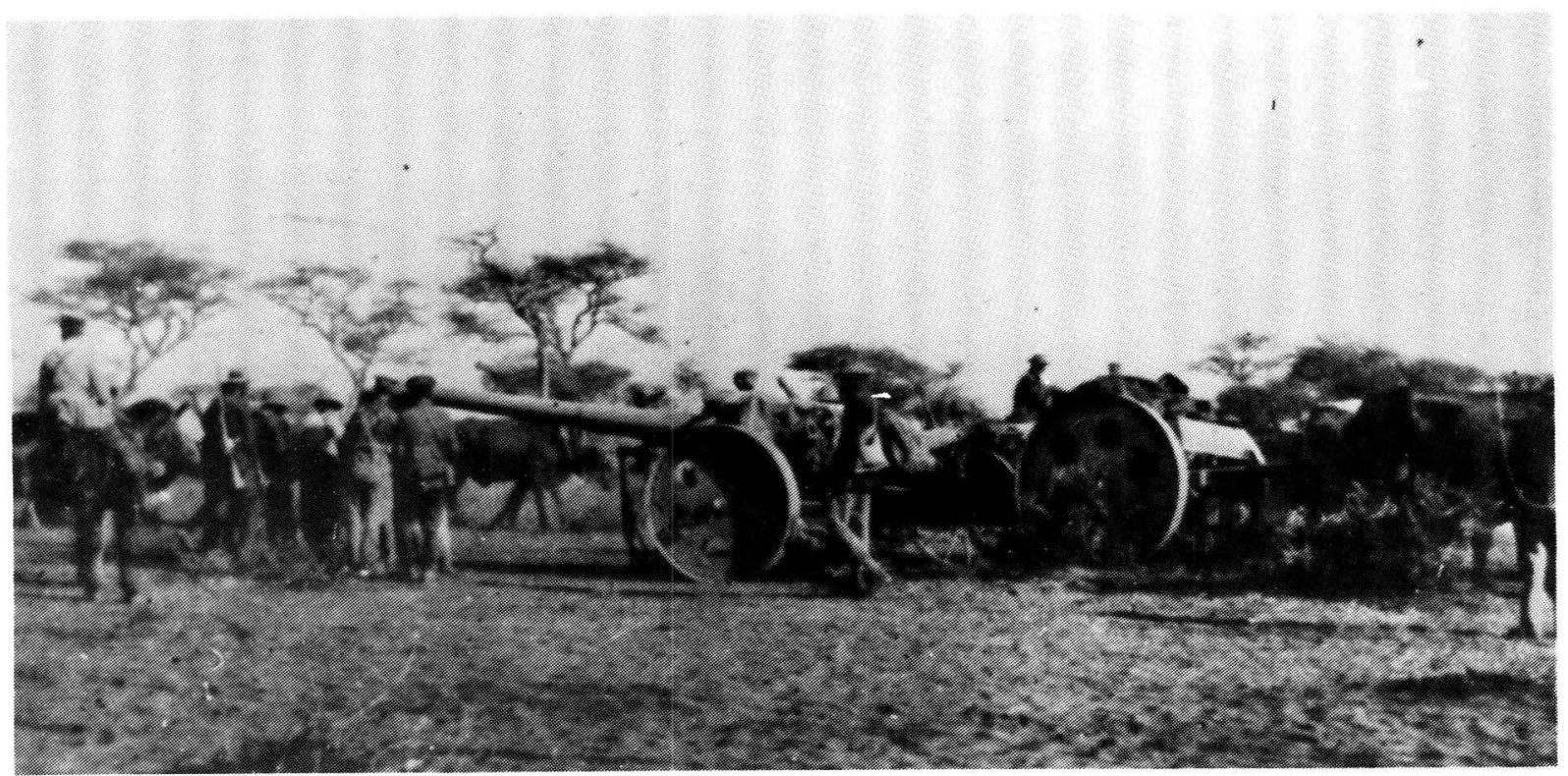

SA Horse Artillery with Guns in South West Africa 
tary staff work at DHQ and for the issue of all military orders by the Minister to the $\mathrm{HQ}$ Staff and the Forces was vested in the CGS. ${ }^{20}$

With the creation of the post of Chief of the General Staff in June 1917, this officer was, in addition, Adjudant-General of the Forces. In October 1919 a seperate post of Adjudant-General was authorized and from 14 October the designation of the original appointment was altered to Chief of the General Staff, Union Defence Forces. ${ }^{21}$ On the retirement of Brigadier General J.J. Collyer, CB, CMG, DSO, Colonel A.J.E. Brinck, DSO, then Deputy-Chief of the General Staff, was promoted Brigadier General and appointed Chief of the General Staff on 21 September 1920.

Owing to retrenchment the post of Inspector General was abolished on 31 December 1921 when the Adjudant-General took over the work of the section. ${ }^{22}$ The CGS had already assumed the functions of Commandant of Cadets in $1918 .^{23}$

The appointments of Secretary for Defence and Chief of the General Staff were combined on 30 September 1922 following the retirement of Sir Roland Bourne, KBE, CMG. The duumvirate system was scrapped as it was considered that it was no longer warranted owing to the military situation in South Africa. ${ }^{24}$

Most of the Imperial garrison left South Africa in 1914 but a number, mainly artillerymen and engineers still remained. The last of the garrison left the Cape Peninsula in 1921. From 1 December 1921 the South African Military Command (the War Office designation for the Imperial military command in South Africa) was abolished and responsibility for the coast defences of the Cape Peninsula formally handed over to a Union commander, Brigadier General Tanner by the Imperial commander, Major General Carter. ${ }^{25}$ The duties of costal defence were then assumed by the UDF, a step which necessitated the formation of the South African Permanent Garrison Artillery.

With the final departure of the Imperial garrison, Act 33 of 1922 (Defence Endowment Property and Account Act) made provision for the transfer of British War Department and Admiralty property to the Union Government.

After the conclusion of World War One, the UDF experienced a decline in its rate of development. The chronic economic situation in South Africa after the War resulted in a drastic shortage of funds for the Defence Force which in fact threatened the viability of the UDF. At this time defence policy was not determined by the military needs of the country but was subordinated to the country's economic capacity. The situation necessitated decisive measures. The main area of economy was that of personnel with considerable retrenchment taking place. Further economies were effected by amalgamating in three instances two military districts for administrative purposes under one District Staff Officer. In the Annual Report for the year ended 30 June 1921. the Secretary stated that the military chiefs were determined to effect all economies possible, short of crippling the future of the defence system.

\section{Reorganization of 1922}

A major attempt to put the UDF on a sounder footing was the reorganization of the early 1920's. In November 1920 the Chief of the General Staff submitted a memorandum containing proposals for the reorganization of the Permanent Force and the establishment of a small purely military force in place of the regiments and batteries of the SA Mounted Rifles as previously constituted. He submitted that "the establishment of an ever-ready and efficient mobile force to uphold the authority of the Government is urgently necessary". Owing to the financial stituation, however, the Government found itself unable to authorize the carrying out of these recommendations, and decided that, for the time being, the Field Force portion of the Permanent Force should be restricted to one regiment of mounted riflemen and three batteries of field artillery; and that the Permanent Coast Defence Forces should be a headquarters and two companies of garrison artillery and a section of fortress engineers.

The South Africa Defence Act Ammendment Act (Act 22 of 1922) was promulgated on 12 July 1922. The Act provided for the reconstitution of the Permanent Force. The system of a military constabularly on which the SAMR was organized under the original defence scheme laid out in the 1912 Act was abondoned. The South African Permanent Force was reconstituted on 1 February 1923 and included the following units established on the same date: SA Staff Corps; SA Instructional Corps; SA Naval Service; SA Field Artillery; 1st Regiment SA Mounted Riflemen; SA Permanent Garrison Artillery; SA Engineer Corps; SA Air Force; SA Service Corps; SA 


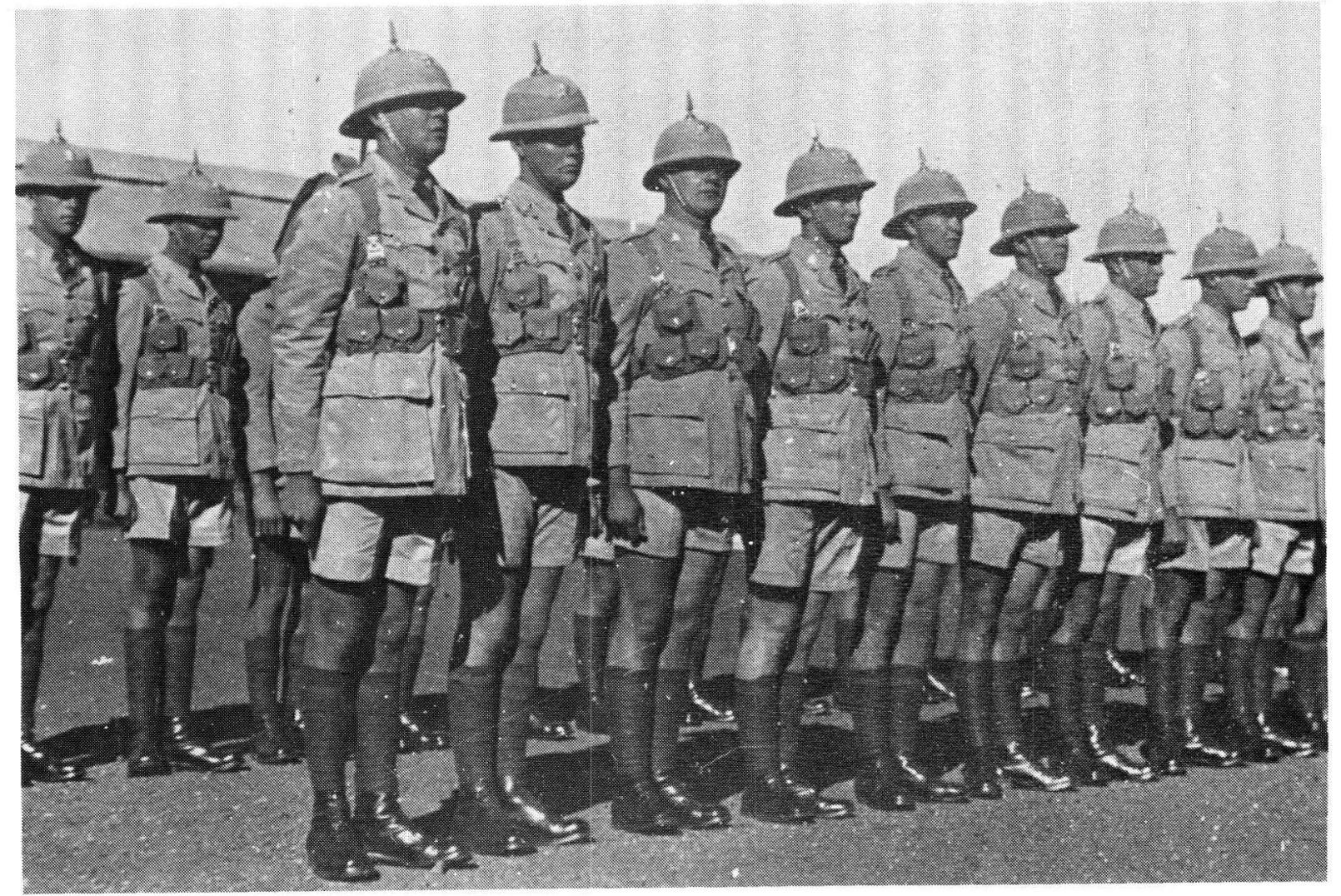

Members of the Special Service Battalion on Parade

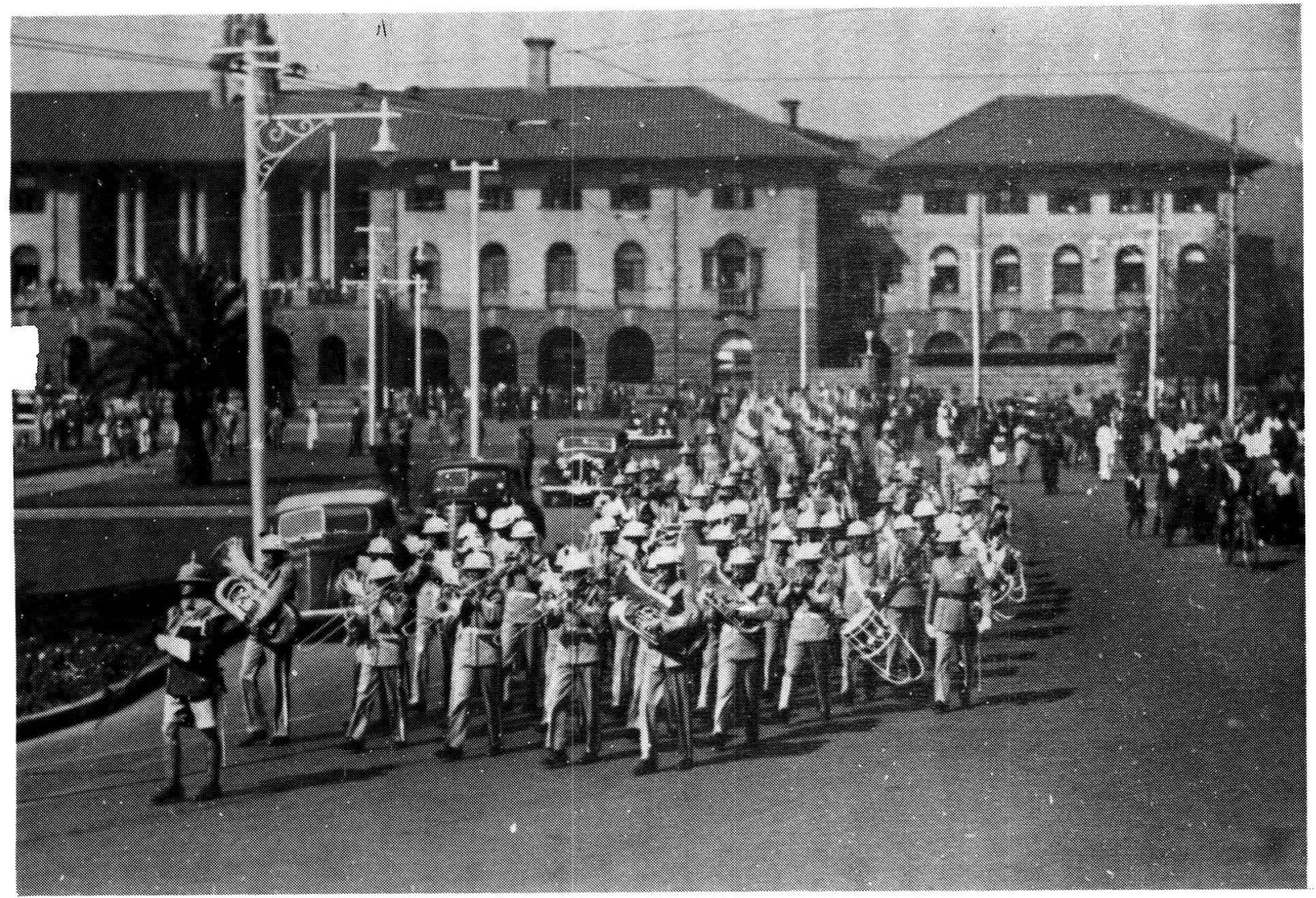


Medical Corps; SA Ordnance Corps; SA Veterinary Corps; and SA Administrative, Pay, and Clerical Corps. ${ }^{26}$

Registration of citizens for peace training which had been discontinued with the outbreak of the War was, in terms of the Act, to be resumed in 1924. Although registration was carried out in January 1925, the provisions of the Act regarding peace training were not being observed. The Government was not prepared to face the expenditure involved in the acceptance of the full quota of citizens for peace training. Despite the shortage of funds the ACF units, Rifle Associations and School Cadets made the best of their limited facilities with ACF units especially trying constantly to uphold their proud traditions.

A distinctive "veld-coloured" South African uniform was introduced and came into force in April $1922 .{ }^{27}$

The South African Military School, previously situated at Tempe, which had been closed during the war was transferred to Roberts Heights in January 1920 and courses of instruction and training classes were recommenced in March 1920. The designation "SA Military School" was changed to "SA Military College" with effect from 1 July 1924.28

\section{Reorganization of 1926}

The necessity for economy in expenditure on defence services necessitated yet further reorganization of the UDF during 1926. The constant changes were by this time seriously disorganizing the administration and interfered unduly with the normal progress of the Department's activities. The last remaining regiment of the SAMR was disbanded on 31 March and the number of military districts was reduced from 15 to 6 on 1 April. The brigade headquarters of the SAFA was disbanded and sections of artillery distributed to various stations in the Union.

Prior to 1928 the ACF consisted of independant units with no higher formation but in that year 1 mounted and 3 infantry brigades were organized. ${ }^{29}$ In 1934 the number of brigades was increased to six

\section{The Depression}

The Great Depression led to an even greater reduction in the Defence budget. ACF conti- nuous training had been considerably reduced over the previous few years but with the even more serious situation, none was held between 1 July 1930 and 30 June 1934. Further moves to reduce expenditure resulted in the disbandment of fourty-nine ACF units of 31 December $1929 .{ }^{30}$ During 1932 the numerical designations of the ACF units were abolished.

An important development in the UDF took place on 1 May 1933 with the establishment of the Special Service Battalion. The unit was established in order to overcome the problem of so many young men being unemployed because of the Depression. During October and November 1933 the military districts were re-designated commands. ${ }^{31}$

\section{Growth}

The upward trend in the economy in 1934 resulted in an increase in the Defence budget. A warning was however sounded that should there be another depression and the procedure of cutting defence expenditure be followed, all the ground gained would be lost. For a number of years the ACF organization in rural districts had been in suspension. Under the new scheme seven regiments were established in the various country districts of the Union and one in a city.

During the Parliamentry debate on the Defence Vote for 1934-35, the Minister of Defence (the Hon O. Pirow), made a statement outlining general defence policy. ${ }^{31 a}$ He summarised the aim of the defence organization as follows:- "The results at the end of five years from now should be: Our air force should comprise three squadrons, one high speed bomber, one general purpose and one tutor squadron for ab initio training. We should have the necessary reserves of men and material for all air force purposes. Our artillery should consist of ten batteries, one wholly and others partly mechanized. Here too, the necessary reserves in men and material should be available. We should have 24 active citizen force battalions specially trained to machine guns and trench mortars. There should be a reserve capable of taking the field within 21 days 25000 similarly trained men who have passed through the special service battalion or the active citizen force. An organisation should exist capable of expanding these battalions and the reserve into full war time regiments with a minimum of delay. We should have a mechanical battalion consisting of a section of tanks, of armoured cars, of armoured planes and two 
armoured trains. We should have adequate coastal defences, including the latest bombing aircraft and mobile coastal artillery. There should be available a reserve of fully trained officers and of efficient non-commissioned officers capable of meeting the whole requirements of the national reserve when called up. We should have a national reserve of riflemen numbering 120000 including 15000 men who have had cadet training. I can summarize the power position as it should exist at the end of five years by saying that, including our permanent force, we should have nearly 56000 reasonably trained and disciplined men and a national reserve of 100000 riflemen. There should be available the necessary military equipment, stores and organization to train, arm, clothe and feed the whole of our national reserve in reasonable stages of mobilization. We should have a staff of highly trained professional soldiers, men capable of carrying out mobilization with a minimum of delay, and capable thereafter of taking the field, and directing whatever measures of offence or defence may be necessary." This was the five year plan which was to occupy the years prior to World War Two.

In 1938 the Minister announced his plans for the extension and reorganization of the Defence Force. A total of $£ 5$ million spread over a period of three years was also made available. Before these plans could be executed, however, World War Two broke out on 3 September 1939. The Union declared war on Germany on 6 September.

South Africa's army played an important part in the Allied victory, fighting in East Africa, the Western Desert, Italy and Madagascar.

\section{Post-war Development}

\section{Consolidation}

After the return to a peacetime footing, at the end of the war, of the huge war machine which had been established, it was fortunate for the Department of Defence that there was no corresponding reduction in armament as was the case after World War One. A period of development and reconstruction followed in the Defence Force which was unknown in peace time in this country.

Commandos and Rifle Associations had preciously been organized on a rather loose footing but their organization as well as their training was now considerably improved.

\section{Gymnasiums}

In 1949 the Gymnasium system which provided training for boys between 16 and 23 was inaugurated. The boys were taught the handling of military weapons as well as a sense of discipline and physical preparedness. Three Gymnasiums were established, namely Military, Air Force and Navy. The Military Gymnasium was established on 1 November 1949 and training commenced on 1 February 1950.

Training of a different nature was undertaken when on 1 April 1950 the Military Academy, a branch of the Military College and affiliated to the University of Pretoria, began to function. BA Mil and BSc Mil-degrees were to be presented at the end of three years. On 1 February 1956 the Military Academy opened at Saldanha Bay in the Cape.

\section{Grouping of formations}

A major part of the reorganization of the land forces since World War Two has been the grouping and regrouping of formations. On 16 May 1946 the Permanent Force Brigade Group at Potchefstroom was designated 11 Armoured Brigade Group. ${ }^{32}$ This development was followed by the establishment on 1 July 1948 of two divisions (1 SA Infantry Division and 6 SA Armoured Division) and 5 brigades (1, 2, 3, 12 and 13 Infantry Brigades). In this new organization 11 Armoured Brigade was brigaded together with 12 and 13 Brigades under 6 SA Armoured Division. ${ }^{33}$ The existence of these formations was however short-lived and with the exception of 11 Brigade they were disbanded on 1 November 1949. ${ }^{34} 11$ Armoured Brigade Group was disbanded on 1 October $1953^{35}$

During the early 1960's 6 Combat Groups were established for the purpose of executing unconventional warfare. The first four, namely 11-14 Combat Groups were established on 1 January $1961^{36}$ and these were followed by 15 and 16 Combat Groups on 1 April 1963. ${ }^{37}$ With the reevaluation of the role of Commands they were disbanded towards the end of the decade.

Since the establishment of 7 SA Division and 17-19 Brigades as well as HQ Communication Zone on 1 April 1965 the Army has maintained 
an organization of conventional formations. ${ }^{38} 7$ SA Division was disestablished on 1 November 1967, the same date as Army Task Force and 16 Brigade were established. ${ }^{39} 7$ SA Division again saw the light of day on 7 July 1971 when Army Task Force was redesignated. ${ }^{40}$

The South African Army today has two divisions and seven brigades. With the exception of 44 Parachute Brigade which was established in 1978, these all came into being on 1 August 1974. 1 South African Corps (which has since been disbanded) formed the apex of this new organization with 7 SA Infantry Division (71-73 Motorised Brigades) and 8 SA Armoured Division (81 Armoured Brigade; 82 Mechanised Brigade and 84 Motorised Brigade) constituting the rest.

\section{National Service}

The second prominent feature of the post-war South African Army has been the necessity to obtain ever-increasing numbers of members. Since the late 1960's this has been to face what has become a threat to the sovereignty of the RSA.

The Active Citizen Force which previously recruited its members on a voluntary basis switched to the ballot system. A citizen who registered for military training and whose name was drawn, was obligated to fulfil the commitment, which affected a varying percentage determined annually according to requirements. The result of this was that National Servicemen were drawn from all sectors of the white population while at the same time also providing more effective methods of dividing the two language groups into different units.

On 1 January 1968 compulsory National Service for all medically fit white South African males was introduced. The period was subsequently increased to twelve months and on 30 September 1977 it was increased to the present period of two years. Military service is not compulsory for women. Since the inception of the Civil Defence College at George in 1971, they have however been able to volunteer for a year's service.

Voluntary National Service is also available to coloured youths, the first of whom reported to the SA Coloured Corps on 15 January 1973. Another important milestone in the history of the Army came a year later when the new uniform was introduced.

\section{Chief of the Army}

The post of Chief of the Army as it exists today can be traced back directly to the appointment of Brigadier P. de Waal to the post of Deputy Chief of Staff on 21 March 1941. ${ }^{41}$ The first of three officers to hold this appointment, he was succeeded by Brigadier General H.S. Wakefield on 9 February $1944 .{ }^{42}$ Colonel H.S. Cilliers followed for a short period from 1 August $1945^{43}$ to 1 March 1946. On 2 March 1946 the post of Deputy Chief of Staff was redesignated Deputy Chief of the General Staff ${ }^{44}$ and the war-time GOC 6 SA Armoured Division, Major General W.H.E. Poole, CB, CBE, DSO, was appointed as the only encumbent. ${ }^{45}$ With the appointment of Maj Gen Poole as the Head of the SA Military Mission, Germany, ${ }^{46}$ the post of DCGS was abolished and a new post, designated DirectorGeneral of Training and Operations, created on 9 August $1948 .{ }^{47}$ Brigadier P. de Waal ${ }^{48}$ filled the post until 9 November $1948^{49}$ when it was redesignated Director-General of Land Forces. ${ }^{50}$ This designation was also short-lived with only two officers, namely Major General C.L. de Wet Du Toit (10 November 1948 - 23 April 195051) and Brigadier H.B. Klopper (24 April 195052 - 30 April $\left.1953^{53}\right)$, filling it.

With the reorganization of the three arms of the UDF in 1951, Director-General of Land Forces was redesignated Army Chief of Staff on 1 July. On his appointment as Inspector-General, Brig Klopper was succeeded by Brigadier P.H. Grobbelaar $^{54}$ who was in turn appointed InspectorGeneral at the end of his term as Army Chief of Staff on 24 September 1958. ${ }^{55}$ Major General J.N. Bierman was next in line in this post, being appointed on 25 September. ${ }^{56}$ The appointment of Major General S.A. Engelbrecht on 1 November $1959^{57}$ followed the move of Maj Gen Bierman to the post of Deputy Inspector-General. During the time that he held the post the rank of Major General was redesignated Combat General and on 4 March $1963^{58}$ he was succeeded by Combat General P.J. Jacobs who filled the position until 31 December 1965.

Combat General C.A. Fraser was appointed Army Chief of Staff on 1 January 1966 and he was promoted to Lieutenant General on the post being redesignated Chief of the Army on 1 July 1966. On the appointment of Lieut Gen Fraser to the post of GOC Joint Combat Forces, Lieutenant General W.P. Louw became Chief of the Army on 1 December 1967. The present Minister of Defence, General M.A. de M. Malan, followed 


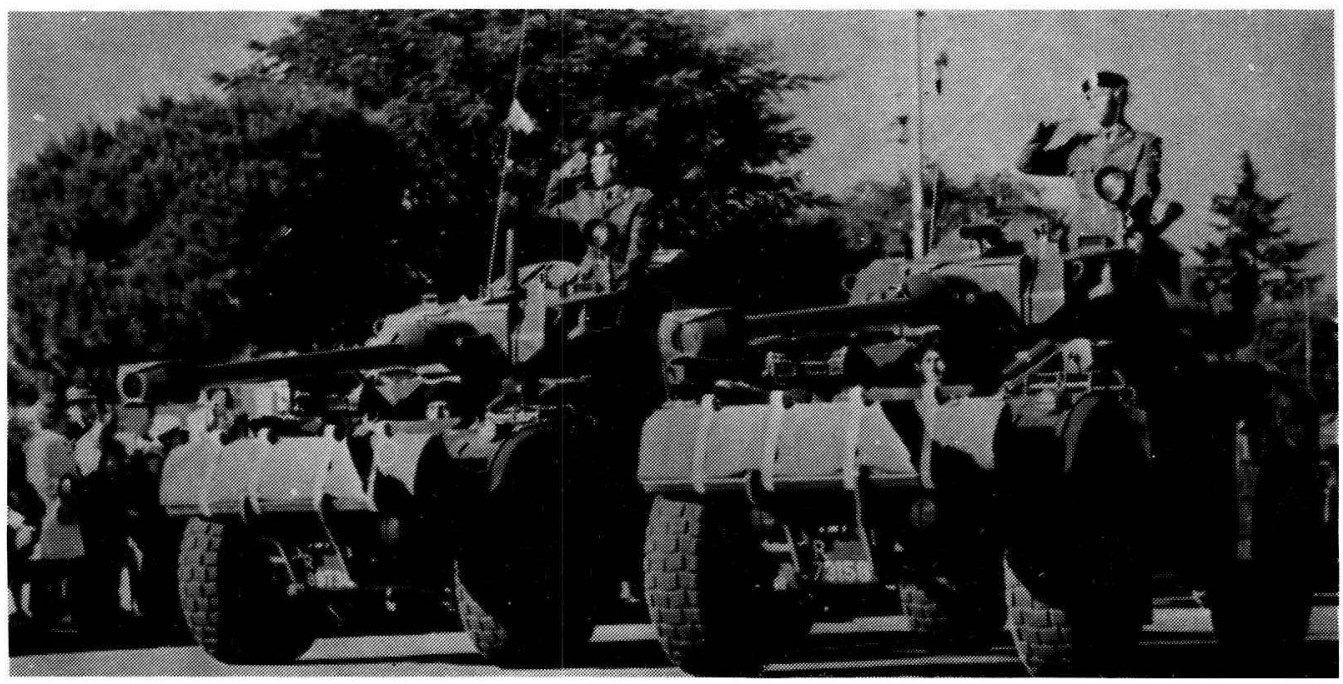

The Eland

Lt Gen Louw on 1 July 1973, holding the post until his promotion to Chief of the SADF on 1 September 1976. General Malan's successor, Lieutenant General C.L. Viljoen was Chief of the Army until 7 October 1980 when the present encumbent Lieutenant General J.J. Geldenhuys was appointed.

\section{Into the future}

Today the Army is a highly efficient fighting machine armed with locally developed weapons such as the Ratel ICV, $127 \mathrm{~mm}$ Multiple Rocket Launcher and the $155 \mathrm{~mm}$ G5; locally produced weapons such as the Eland Armoured Car and the R4 assault rifle; local modifications of World War Two weapons such as the Olifant Tank (the first Centurions arrived in South Africa in 1952); and even weapons such as the Vickers, Bren and Browning machine guns.

The South African Army has come a long way since the days of economic stringency when it was hardly a viable organization and with a proud fighting record which men have fought and died for it is an Army of which the Republic of South Africa can be proud.

\footnotetext{
* Sgt A.C. Lillie is attached to Sub-section Enquiries at Military Information Bureau and is at present in his second year of study for the B Journ degree at Rhodes University
}

\section{Footnotes}

1. G.N. No 8 of 31 May 1910 U.G. 7 June 1910

2. U.G. $61-13$ p. 1

3. G.N. No 922 of 3 July 1912 U.G. 5 July 1912.

4. G.N. No 921 of 3 July 1912 U.G. 5 July 1912.

5. G.N. No 871 of 22 June 1912 U.G. 26 June 1912

6. G.N. No 923 of 3 July 1912 U.G. 5 July 1912 (Sir Duncan McKenzie was promoted to the nonoury rank of Brigadier-General on his retirement on 1 July 1912).
7. G.N. No 921 of 3 July 1912 U.G. 5 July 1912.

8. G.N. No 1532 of 6 November 1912 and G.N. No 1068 of 30 June 1914 U.G. 3 July 1914

9. G.N. No 1620 of 27 November 1912.

10. U.G. $61-13$ p. 16

11. U.G. $61-13$ p. 1.

12. G.N. No 1703 of 12 December 1912 U.G. 17 December 1912.

13. Sec 44 Act 13 of 1912

14. U.G. $16-13$ p. 21

15. U.G. $16-13$ p. 21 and G.N. No 434 of 27 February 1913 U.G. 14 March 1913

16. G.N. No 1534 of 6 November 1912 U.G. 8 November 1912 G.N. No 1552 of 4 October 1913 U.G. 10 October 1913.

17. G. 0.684 and 687

18. G.0. 684 .

19. G.0. 1637

20. Annual Report: Department of Defence 1921. pp. 8 \& 9 .

21. G.0. 3208

22. G.0. 4289 (d)

23. Annual Report: Department of Defence 1921. p. 12.

24. Annual Report: Department of Defence 1922. pp. 10 \& 11 .

25. Annual Report: Department of Defence 1922. p. 1.

26. Procolomation No 17 of 1923. Supplement to the Government Gazette of 26 January 1923

27. Annual Report: Department of Defence 1922. p. 32.

28. Annual Report: Department of Defence 1925. p. 6

29. Annual Report: Department of Defence 1928. pp. 5 \& 7 UG 44-28.

30. Annual Report: Department of Defence 1930. p. 13 UG 39-'30.

31 a. Annual Report: Department of Defence 1934. pp. 9 \& 10 UG 47-34.

32. R.0. 1253.

33. G.N. No 1787 dd 27 August 1948 G.G. 27 August 1948

34. SADF Archives.

35. SADF Archives.

36. SADF Archives.

37. SADF Archives.

38. SADF Archives.

39. SADF Archives.

40. SADF Archives.

41. F.0. 2624.

42. F.0. 3153.

43. F.0. 3833.

44. R.0. 1244.

45. F.0. 3840.

46. F.0. 4171.

47. R. 0.1423

48. F.0. 4167 .

49. F.0. 4279

50. R.O. 1455.

51. SADF Archives.

52. SADF Archives

53. SADF Archives.

54. SADF Archives.

55. SADF Archives

56. ibid.

57. SADF Archives.

58. SADF Archives 